\title{
C-erb-B2 (Her2/neu) Expression Rate And its Association with Clinicopathologic Parameters in Gastric Cancer
}

\author{
Sukru YILDIRIM ${ }^{1}$, Ozgur DANDIN ${ }^{2}$, Muzaffer DURMUS ${ }^{3}$, Ugur KARAPINAR ${ }^{4}$, Murat ASLAN AS, $^{5}$ \\ Mehmet GOKCE ${ }^{6}$, Fadime SAHIN ${ }^{6}$ \\ ${ }^{1}$ Bursa Military Hospital, Department of Pathology, Bursa, TURKEY \\ ${ }^{2}$ Bursa Military Hospital, Department of General Surgery, Bursa, TURKEY \\ ${ }^{3}$ Bursa Military Hospital, Department of Plastic and Reconstructive Surgery, Bursa, TURKEY \\ ${ }^{4}$ Bursa Military Hospital Department of Ear Nose Throat, Bursa, TURKEY \\ ${ }^{5}$ Bursa Military Hospital, Department of Oncology, Bursa, TURKEY \\ ${ }^{6}$ Patomer Pathology Laboratory, Bursa, TURKEY
}

\begin{abstract}
We aimed to investigate the frequency of C-erb-B2 expression rate and its association with clinicopathological parameters in our gastric carcinoma series to make a contribution to emerging data on this oncogene. One hundred thirty-nine gastric adenocarcinoma patients underwent total gastrectomy between years 2006 and 2011 were selected to the study. C-erb-B2 expressions were determined by using immunohistochemical and/or chromogenic in situ hybridisation methods in tumor tissues. A total of 16 (11.5\%) gastric adenocarcinoma cases were found positive for c-erb-B2 expression. Out of 16 positive cases, 13 had intestinal type adenocarcinomas. C-erb-B2 overexpression was significantly associated with histologic subtype $(p=0.001)$, and histologic tumor grade $(p=0.001)$. The frequency of overexpression in intestinal subtype $(21.7 \%)$ was comparable with the known rates of overexpression in breast cancer. This results indicate that C-erb-B2 expression may identify a subgroup in gastric carcinoma cases which may benefit from targeted treatment modalities among Turkish population.
\end{abstract}

Keywords: C-erb-B2, Gastric adenocarcinoma, Immunohistochemistry, Trastuzumab

\section{ÖZET}

Mide Kanserinde C-Erb-B2 (Her2/Neu) Ekspresyon Sıklığı ve Klinikopatolojik Parametrelerle ilişkisi

Bu çalışma, mide kanseri nedeni ile gastrektomi uygulanmış hasta serimizde C-erb-B2 ekspresyonunun sıklığını belirlemek ve C-erbB2 ekspresyonu ile klinikopatolojik parametreler arasındaki liş̧kiyi araştırmak üzere gerçekleştirilmiştir. Çalısma 2006-2011 yılları arasında opere edilen 139 hastaya ait gastrektomi materyalinde yapılıştır. Tümör dokularında C-erb-B2 ekspresyonlarının saptanmasında primer antikorlar ile ilgili prosedüre göre immunohistokimya ve/veya kromojenik in-situ hibridizasyon yöntemleri kullanılmışıı. Olguların 16 tanesinde (\%11.5) C-erb-B2 ekspresyonu saptanmıştır. C-erb-B2 ekspresyonu görülen 16 tümörün 13 tanesi intestinal tip adenokanser olup, C-erb-B2 ekspresyonu ile tümörün histolojik tipi arasında istatistiksel olarak anlamlı bir ilişki izlenmiştir ( $p=0.001)$. Ayrıca C-erb-B2 pozitifliği ile histolojik grade arasında da kuvvetli bir ilişki saptanmıştır $(p=0.001)$. Intestinal subtip mide kanserlerindeki saptanan pozitiflik oranı (\%21.7), meme kanserlerinde görülen sıklığa benzer düzeydedir. Bu sonuçlar, mide kanseri olgularında c-erb-B2 ekspresyonunun, hedefe yönelik tedavi yaklaşımlarından fayda görebilecek bir hasta grubunu ayırt etmede kullanılabileceğini düşündürmektedir.

Anahtar Kelimeler: C-erb-B2, Gastrik adenokarsinom, Immunohistokimya, Trastuzumab 


\section{INTRODUCTION}

The human epidermal growth receptor 2 (Her2/neu) gene is located on chromosome 17 (q21) and codes a transmembrane receptor protein which is also known as C-erb-B2. Her2/neu is a member of the human epidermal growth factor receptor (EGFR) gene family and it is accepted to be involved in the regulation of cell growth, proliferation and survival. ${ }^{1,2}$ Overexpression of C-erb-B2 occurs in 10\%$34 \%$ of invasive breast cancer patients and it is associated with agressive behaviour, resistence to treatment with chemotherapeutics, and poor response to endocrine treatment. C-erb-B2 overexpression has also been observed in various types of cancers including colon, bladder, ovary, endometrium, lung, uterine cervix, head \& neck, esophageus, and stomach carcinomas. ${ }^{2,3,4}$ Immunohistochemical (IHC) staining or DNA hybridisation methods such as fluorescence in situ hybridisation (FISH) and chromogenic in situ hybridisation (CISH), are commonly used to evaluate the C-erb-B2 overexpression/amplification in different tumor types. Among these methods, immunohistochemistry has advantages with shortest turn around times, being a cost effective method, and the relative simplicity in assessment of Her-2/neu expression. In IHC method, a semiquantitative scoring system, ranges from $(+)$ to (+++) staining is widely accepted to evaluate Her-2/neu expression.

Recently, trastuzumab, a monoclonal antibody against the C-erb-B2 receptor, has been demonstrated to prolong survival of the patients with breast cancer or advanced gastric cancer, by down regulating the C-erb-B2 receptor function. ${ }^{4.5}$ Since, patients with tumors that have $\mathrm{C}$-erb-B2 overexpression benefit from trastuzumab therapy, it is essential to determine the C-erb-B2 status of tumors to use trastuzumab as an additional agent in treatment of related cancers.

Gastric carcinoma is one of the most common cause of cancer related deaths worldwide. It arises from the glandular tissue of the stomach lining. In its therapeutic management, a combined multidisciplinary approach such as surgery, chemotherapy and radiotherapy is required. After addition of trastuzumab to standard chemotherapy is reported to improve patient survival, C-erb-B2 expression status has been widely studied in gastric cancer. ${ }^{6}$ It is implicated that the ratio of C-erb-B2 overexpression may also differ between the subtypes of gastric cancer. ${ }^{3}$ In the present study we aimed to investigate the frequency of C-erb-B2 expression in gastric carcinoma cases and to determine the relationship of overexpression with known prognostic parameters among Turkish population to make a contribution to the emerging data.

\section{MATERIALS AND METHODS}

One hundred and thirty-nine gastric adenocarcinoma patients that underwent total gastrectomy between years 2006 and 2011 were identified from the pathology laboratory archieve comprising the specimens obtained from several hospitals; Medical Park Hospital, Anadolu Hospital, Medice Hospital, Medicabil Hospital to a private pathology laboratory (Patomer Pathology Laboratory) in Bursa, Turkey. Each patient gave written informed consent before the surgery and the study was conducted in accordance with Declaration of Helsinki and approved according to Turkish Ethical regulation. Routinely fixed (overnight in 10\% buffered formallin) paraffin- embedded tumor samples were used in the study. H\&E stained slides and the respective paraffin blocks were retrieved from the archieve and were histologically revised. Subtyping of the tumors were made according to the World Health Organization (WHO) criterias. For immunostaining, sections were cut in 3 micrometer thickness. IHC staining was conducted using anti-C-erb-B2 antibodies (Biocare ${ }^{\circledR}$ Medical Cat. No: CME 342 AB, Clone EP1045Y 1/100 concentrated rabbit monoclonal, 4040 Pke Lane Concord, CA 94520 USA) according to manufacturer instructions.

To evaluate the expressions, a previously reported semiquantitative scoring system was carried out and specific membraneous staining was taken under consideration. ${ }^{7}$ The slides were examined and scored by two experienced pathologists independently to avoid subjective bias. Evaluation of the results was performed by assigning a score of 0 to $3+$ (Table 1). Representative samples of each staining score are demonstrated in Figures 1-4. Cases were divided into two groups according to immunostaining pattern:

Tumors with a score of 0 or $1+$ were regarded as being C-erb-B2-negative (Group I), while score of 3+ 


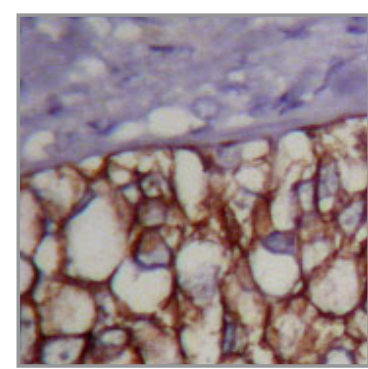

Figure 1. Membraneous Her/2Neu expression on breast carcinoma used for positive control; Score 3 (x200 DAB Chromogen).

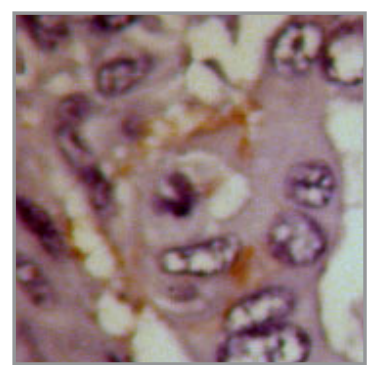

Figure 2. Focal weak Her2/Neu expression in gastric carcinoma; Score 1. (x400 DAB Chromogen). indicated positive expression of C-erb-B2 (Group II). For cases with $2+\mathrm{C}$-erb-B2 expression, CISH assays were performed to determine the final score. Standart $5 \mu \mathrm{m}$ thick tumor sections were treated according to CISH kit procedure (ZytoDot ${ }^{\circledR} 2 \mathrm{C}$ amplification and visualization kit and SPEC HER2 $\backslash$ CEN17 Probe kit, ZytoVision ${ }^{\circledR}$ GmbH, Bremerhaven, Germany). Ratio of green dots, corresponding to Her2 gene, to red dots, representing the centromeric region of chromosome 17 , were calculated after evaluating at least 100 tumor cells per tumor. Scores higher than 2 were accepted as amplification of Her2 gene. Tumors with other scores were considered as not amplified. According to CISH results, tumors with Her2 amplification were included in group II (positive cases), whereas, tumors that showing no amplification of Her2 gene were included in group I (negative cases).

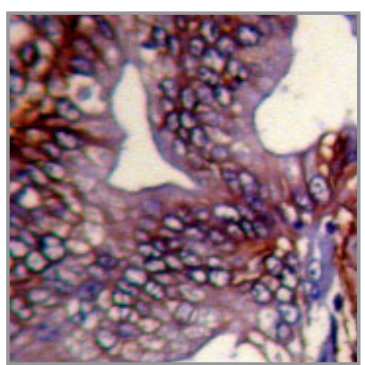

Figure 3. Focal strong membraneous expression in gastric carcinoma. Staining in more than $10 \%$ of tumor cells ; score 2. (x200 DAB Chromogen).

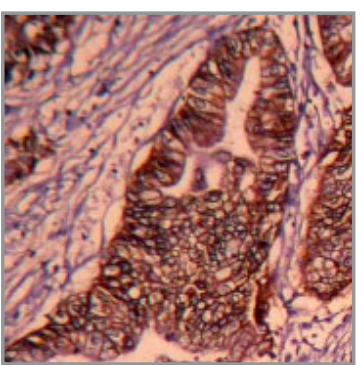

Figure 4. Strong membraneous expression in gastric carcinoma. Staining in more than $50 \%$ of tumor cells; score 3 (x100 DAB Chromogen).
Statistical Analysis: Continuous variables were given as mean \pm standard deviation; cathegorical variables were defined as percentages. Continuous variables were compared by Student t-test and the $\chi^{2}$ tests were used for analysing the differences in cathegorical variables between two groups. All $\mathrm{p}$ values were two-tailed, and statistical significance was defined as $\mathrm{p}<0.05$. The SPSS statistical software (SPSS 15.0 for windows, Inc., Chicago, IL, USA) was used for all statistical calculations.

\section{RESULTS}

Mean patient age was 59.1 \pm 14 years old (range 27 - 89 years). Out of 139 cases, 79 (56.8\%) were diagnosed with diffuse type and a subset of 60 (43.2\%) patients were diagnosed with intestinal type. In immunohistochemical examination, 113 $(81.3 \%)$ of 139 cases were negative for C-erb-B2

\begin{tabular}{|c|c|c|c|c|}
\hline Score & Pattern & Classification & $\mathbf{N}$ & Group \\
\hline 0 & No staining or membrane staining in $<10 \%$ of the tumor cells; & NEGATIVE & 113 & Group I \\
\hline $1+$ & $\begin{array}{l}\text { Faint/barely perceptible membrane staining in }>10 \% \text { of the tumor cells, } \\
\text { cells stained in part of the membrane; }\end{array}$ & NEGATIVE & 8 & \\
\hline $2+$ & $\begin{array}{l}\text { Weak to moderate staining of the entire or basolateral membrane } \\
\text { staining in }>10 \% \text { of the tumor cells; }\end{array}$ & $\begin{array}{l}\text { EQUIVOCAL } \\
\mathrm{CISH}(-)\end{array}$ & 2 & \\
\hline $2+$ & $\begin{array}{l}\text { Weak to moderate staining of the entire or basolateral membrane } \\
\text { staining in }>10 \% \text { of the tumor cells; }\end{array}$ & $\begin{array}{l}\text { EQUIVOCAL } \\
\mathrm{CISH}(+)\end{array}$ & 4 & Group II \\
\hline $3+$ & $\begin{array}{l}\text { Moderate to strong staining of the entire or basolateral membrane } \\
\text { staining membrane in }>10 \% \text { of the tumor cells. }\end{array}$ & POSITIVE & 12 & \\
\hline
\end{tabular}




\begin{tabular}{|c|c|c|c|c|c|c|c|c|c|c|}
\hline & & & \multicolumn{2}{|c|}{$\begin{array}{l}\text { Group2, } \\
\text { Her2/neu } \\
\text { positive } \\
n=16\end{array}$} & \multicolumn{2}{|c|}{$\begin{array}{l}\text { Group1, } \\
\text { Her2/neu } \\
\text { negative } \\
n=123\end{array}$} & \multirow{2}{*}{$\begin{array}{l}\begin{array}{l}\text { Our } \\
\text { study }\end{array} \\
\text { p value }\end{array}$} & \multirow{2}{*}{$\begin{array}{l}\text { Tanner } \\
\text { (3) } \\
\text { p value }\end{array}$} & \multirow{2}{*}{$\begin{array}{l}\text { Kim } \\
(10)\end{array}$} & \multirow{2}{*}{$\begin{array}{l}\text { Xie } \\
\text { (19) } \\
\text { p value }\end{array}$} \\
\hline & & & $\mathbf{n}$ & $\%$ & $\mathbf{n}$ & $\%$ & & & & \\
\hline & & & 16 & 11,5 & 123 & 88,5 & & & & \\
\hline Age & & & $55 \pm 13$ & $60 \pm 14$ & 0.173 & 0,17 & $\mathrm{NS}^{*}$ & 0,019 & & \\
\hline \multirow[t]{2}{*}{ Sex } & Male & 82 & 7 & 8.5 & 75 & 91.5 & 0.188 & 0,43 & $\mathrm{NS}^{*}$ & 0,131 \\
\hline & Female & 57 & 9 & 15.8 & 48 & 84.2 & & & & \\
\hline Histologi- & Intestinal & 60 & 13 & 21.6 & 47 & 78.4 & 0.001 & 0,0051 & 0,001 & - \\
\hline \multirow[t]{2}{*}{ cal type } & Diffuse & 75 & 3 & 4 & 72 & 96 & & & & \\
\hline & Mixed & 4 & 0 & 0 & 4 & 100 & & & & \\
\hline Histologi- & Grade 1 & 4 & 0 & 0 & 4 & 100 & 0.001 & - & 0,001 & 0,476 \\
\hline \multirow[t]{2}{*}{ cal grade } & Grade 2 & 56 & 13 & 23.2 & 43 & 76.8 & & & & \\
\hline & Grade 3 & 79 & 3 & 3.7 & 76 & 96.3 & & & & \\
\hline Lymph Node & pNO & 23 & 2 & 8.7 & 21 & 91.3 & 0.113 & - & - & 0,472 \\
\hline \multirow[t]{3}{*}{ Status } & $\mathrm{pN} 1$ & 43 & 2 & 4.6 & 41 & 95.4 & & & & \\
\hline & $\mathrm{pN} 2$ & 43 & 9 & 21 & 34 & 79 & & & & \\
\hline & pN3 & 30 & 3 & 10 & 27 & 90 & & & & \\
\hline \multirow[t]{4}{*}{ Staging } & $\mathrm{pT} 1$ & 4 & 1 & 25 & 3 & 75 & 0.754 & 0,42 & $\mathrm{NS}^{*}$ & - \\
\hline & pT2 & 16 & 2 & 12.5 & 14 & 87.5 & & & & \\
\hline & pT3 & 92 & 11 & 12 & 81 & 88 & & & & \\
\hline & pT4 & 27 & 2 & 7.4 & 25 & 92.6 & & & & \\
\hline
\end{tabular}

expression (score 0), and 8 (5.8\%) cases showed incomplet membraneous staining in less than $10 \%$ of tumor cells and they were scored as $1(+)$. A total of 121 cases, consisted of 8 tumors with $1(+)$ staining and 113 unstained tumors were included to group I. Twelve (8.6\%) cases revealed strong complete membraneous staining in more than $10 \%$ of tumor cells. These 12 cases were included in group II. In the rest $6(4.3 \%)$ cases, there was weak to moderate staining of the entire or basolateral membrane staining in $>10 \%$ of the tumor cells. These 6 cases were scored as $2(+)$ immunohistochemically. In CISH assay, 4 out of 6 cases showed amplification whereas 2 of them did not. Those cases showing amplification in CISH assay were included in gro- up I, while 2 of 6 cases showing no amplification were included in group II. After CISH results, the number of C-erb-B2 negative (group I) cases were $123(88.5 \%)$ and the number of C-erb-B2 positive (group II) cases were 16 (11.5\%).

Patient demographics and pathological tumor characteristics with respec to C-erb-B2 expression results in our study group are summarised in Table 2. Thirteen out of $16(81.3 \%)$ tumors in group II were intestinal type gastric adenocarcinomas, whereas 3 tumors (18.7\%) were of diffuse type adenocarcinomas. Of 60 intestinal type adenocarciomas, 13 (21.6\%) cases showed Her2/neu expression, whereas only $3(4.0 \%)$ of 75 diffuse gastric carcinomas were found positive. Intestinal type tumors showed 
approximately five times more positivity than diffuse type did. The difference of C-erb-B2 overexpression rates between intestinal and diffuse type carcinomas was statistically significant $(\mathrm{p}=0.001)$. When compared to histological grade I or III cancers, the proportion of C-erb-B2 overexpressing tumors were also significantly higher in histological grade II tumors $(p=0.001)$. The association between C-erb-B2 overexpression and lymph node involvement was not statistically significant. Also we did not observe an association between pathological tumor stage and C-erb-B2 overexpression. Distributions of mean patient age were similar for all groups, and C-erb-B2 overexpression did not differ between both gender groups.

\section{DISCUSSION}

Although the prevalence of gastric adenocarcinoma has decreased in the last decade, it is still the second most common cause of cancer death after lung cancer worldwide. ${ }^{8}$ Despite advances in management of gastric carcinoma, the outcome is poor, especially for patients with advanced stage disease. Therefore, targeted therapies have been introduced to improve the response rates. Her2/neu gene is one of the potential targets and attracted the researchers because its amplification is common in various solid tumors. ${ }^{9}$ The demonstration of C-erb-B2 overexpression in breast cancer provided new insights in treatment of these cancers. Blockadge of C-erb$\mathrm{B} 2$ receptors help the cessation of growth signaling pathway in cancer cells, and prevents the tumor proliferation. Trastuzumab, an antibody against these receptors, is widely used in treatment of breast cancers with C-erb-B2 overexpression.

Carcinogenesis in gastric adenocarcinomas, which includes genetic alterations such as the activation of oncogenes and the inactivations of tumor suppressor genes, is a multistep process occuring in many other cancer types. ${ }^{10-12}$ It has been reported that gastric adenocarcinomas may also show C-erb-B2 overexpression, providing a new choice in treatment of gastric adenocarcinomas. Thus, demonstration of C-erb-B2 receptor status in gastric carcinomas has been thought to be essential in treatment of these cancers. Since gene amplification is well correlated with protein expression levels, IHC methods are preferentially used to determine the $\mathrm{C}$-erb-
B2 receptor proteins in tumor cells. In situ DNA hybridisation methods such as fluorescence in situ hybridisation (FISH) and chromogenic in situ hybridisation (CISH) assays are also used to detect Her2/neu amplification. ${ }^{13,14}$

In the present study, the C-erb-B2 status was assessed by the IHC staining in 139 gastric tumors. A total of 121 tumors were found negative for C-erb-B2 expression, whereas, 12 cases were positive by IHC staining. For the remaining 6 cases, reevaluation was done by using CISH method. C-erb-B2 amplification was observed in 4 of 6 cases. Out of 16 cases with C-erb-B2 overexpression, 13 had intestinal type adenocarcinomas and 3 had diffuse type adenocarcinomas. C-erb-B2 overexpression rates in gastric carcinomas range from $8.2 \%$ to $53.4 \% .6 \mathrm{In}$ our series, this rate was $11.5 \%$ which is concordant with previous studies. Discrepancies in reported Cerb-B2 overexpression rates may caused by the usage of different antibody clones, alternative scoring systems, or heterogeneous staining of tumor tissues. More importantly, it is speculated that evaluation of C-erb-B2 IHC staining is more subjective in gastric cancer than in breast cancer because of higher background staining. However, it usually gives the information of C-erb-B2 expression status of these tumors. ${ }^{3}$ At least, negative cases may be identified by IHC staining and selection for hybridisation methods may be facilitated. Immunohistochemically moderate or weak positive cases may be confirmed by the hybridisation methods.

Since, gastric carcinomas showing C-erb-B2 overexpression are associated with several genetic alterations and characterised by DNA amplification, membraneous protein expression may reveal a distinct subgroup with specific clinicopathologic characteristics and different therapeutic approach requirements. ${ }^{10,15-19}$ Therefore, we were also interested in the relationship between clinicopathologic characteristics and C-erb-B2 expressions in gastric carcinomas. Tanner et al., reported that gastric carcinomas with C-erb-B2 overexpression were associated with the well or moderately differentiated histo$\operatorname{logy} .^{3}$ Our results confirm the association between C-erb-B2 overexpression and histological grade in gastric cancer. We found the proportion of C-erbB2 positive tumors in moderately differentiated carcinomas as six-fold of the high grade tumors $(\mathrm{p}=$ 
0.001). Although this difference was also evident between low and moderate grade tumors, the small number of well differentiated tumors in our study group was insufficient to make a such conclusion between both groups.

C-erb-B2 overexpression was also significantly associated with intestinal type histology in our patient cohort. The rate of C-erb-B2 positive cases in intestinal type gastric carcinomas were $21.6 \%$, which is comparable with the rates of invasive breast cancer. However, further research is warranted to evaluate Trastuzumab sensitivity in C-erb-B2 positive intestinal type gastric cancers among our population. On the other hand, the striking difference in C-erb-B2 overexpression rates between diffuse and intestinal subtypes suggest that different molecular alterations may play a role in pathophysiology of this heterogeneous disease. Unfortunately, the low incidence of overexpression found in diffuse type carcinomas suggests that a limited number of patients may benefit from Trastuzumab therapy, whereas, the vast majority of the patients with this more aggressive subtype of gastric carcinoma will probably lack this treatment choice.

Although mean patient age of group I was slightly lower than group II patients, the difference was not significant. A slight but not significant difference in C-erb-B2 overexpression rates was also observed between two gender groups. Lymph node involvement rates and tumor stages were similar for both groups.

In conclusion, results of our study indicate that Cerb-B2 overexpression is mainly limited to intestinal subtype, and occurs in a moderately differentiated substantial part of the gastric carcinoma cases among Turkish population. It will be expected that the frequent overexpression of C-erb-B2 found in intestinal subtype would have an impact on treatment modalities of this tumor subtype. Therefore, further investigations in larger patient cohorts are needed to clarify its prognostic and therapeutic importance.

\section{REFERENCES}

1. Hilton DA, West KP. C-erbB-2 oncogene product expression and prognosis in gastric carcinoma. J Clin Pathol 45: 454-456, 1992.
2. Chiu KY, Loke SL, Ho FC. Immunohistochemical demonstration of c-erbB2 oncoprotein in gastric adenocarcinoma: Comparison of cryostat and paraffin wax sections and effect of fixation. J Clin Pathol 47: 117121, 1994.

3. Tanner M, Hollmén M, Junttila $\Pi$ et al. Amplification of HER-2 in gastric carcinoma: association with Topoisomerase lla gene amplification, intestinal type, poor prognosis and sensitivity to trastuzumab. Ann of Oncol 16: 273-278, 2005.

4. Allgayer H, Babic R, Gruetzner KU et al. c-erbB-2 Is of Independent Prognostic Relevance in Gastric Cancer and Is Associated With the Expression of Tumor-Associated Protease Systems. J Clin Oncol 18: 2201-2209, 2000.

5. De Vita F, Giuliani F, Silvestris N et al. Human epidermal growth factor receptor 2 (HER2) in gastric cancer: a new therapeutic target. Cancer Treat Rev 36 (Suppl 3); 11-5, 2010.

6. Jørgensen JT. Targeted HER2 Treatment in Advanced Gastric Cancer. Oncology 78: 26-33, 2010.

7. Rüschoff J, Dietel M, Baretton $\mathrm{G}$ et al. HER2 diagnostics in gastric cancer-guideline validation and development of standardized immunohistochemical testing. Virchows Arch 457: 299-307, 2010.

8. Cirne-Lima FK, Rosa AS, Kulczynski JM et al. Immunohistochemical expression of HER-2/NEU-C-ERB-2 in patients with adenocarcinoma of the stomach. Rev Col Bras Cir 36: 131-134, 2009.

9. Baselga J. Why the epidermal growth factor receptor? The rationale for cancer therapy. Oncologist 7 Suppl 4: 2-8, 2002.

10. Kim MA, Jung EJ, Lee HS et al. Evaluation of HER-2 gene status in gastric carcinoma using immunohistochemistry, fluorescence in situ hybridization, and real-time quantitative polymerase chain reaction. Human Pathology 38:1386-1393, 2007.

11. Lee HS, Lee HK, Kim HS et al. Tumour suppressor gene expression correlates with gastric cancer prognosis. J Pathol 200: 39-46, 2003.

12. Fearon ER, Vogelstein B. A genetic model for colorectal tumorigenesis. Cell 61: 759-767, 1990.

13. Ishikawa $\mathrm{T}$, Kobayashi $\mathrm{M}$, Mai $\mathrm{M}$ et al. Amplification of the c-erbB-2 (HER-2/neu) gene in gastric cancer cells. Detection by fluorescence in situ hybridization. Am J Pathol 151: 761-768, 1997.

14. López-Guerrero JA, Navarro S, Noguera R et al. Histological tumor grade correlates with HER2/c-erB-2 status in invasive breast cancer: a comparative analysis between immunohistochemical (CB11 clone and Herceptest), FISH and differential PCR procedures. Arkh Patol 65: 50-55, 2003.

15. Takehana T, Kunitomo K, Kono K et al. Status of CerbB-2 in gastric adenocarcinoma: a comparative study of immunohistochemistry, fluorescence in situ hybridization and enzyme-linked immuno-sorbent assay. Int J Cancer 2002; 98: 833-7. 
16. Nakajima M, Sawada H, Yamada Y et al. The prognostic significance of amplification and overexpression of c-met and c-erb B-2 in human gastric carcinomas. Cancer 85: 1894-1902, 1999.

17. Rebischung C, Barnoud R, Ste'fani $L$ et al. The effectiveness of trastuzumab (Herceptin) combined with chemotherapy for gastric carcinoma with overexpression of the c-erbB-2 protein. Gastric Cancer 8: 249 252, 2005.

18. Matsui $\mathrm{Y}$, Inomata M, Tojigamori M, et al. Suppression of tumor growth in human gastric cancer with HER2 overexpression by an anti-HER2 antibody in a murine model. Int J Oncol 27: 681-685, 2005.

19. Xie SD, Xu CY, Shen JG, Jiang ZN, Wang LB. HER $2 /$ neu protein expression in gastric cancer is associated with poor survival. Molecular Medicine Reports 2: 943-946, 2009.

\section{Correspondence}

Dr. Muzaffer DURMUŞ

Bursa Askeri Hastanesi

Plastik ve Rekonstrüktif Cerrahi Bölümü

Hamam Caddesi Çekirge, Osmangazi

Bursa / TURKEY

Tel : (+90.224) 2246350

Fax : (+90.224) 2245464

e-mail: drmzfdurmus@yahoo.com 